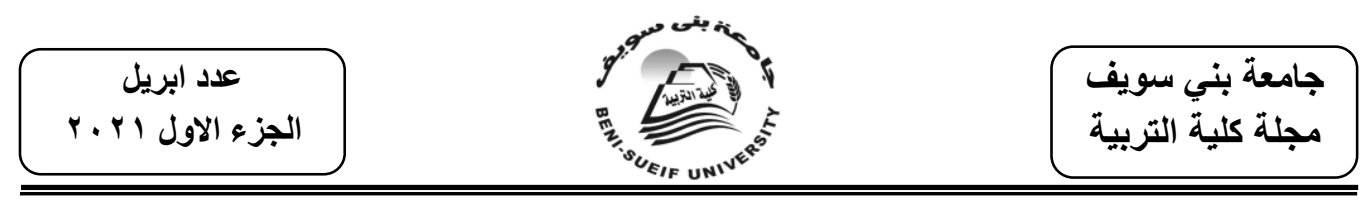

\title{
Using the Negotiation Strategy for Enhancing EFL Students' Active Listening Skills \\ By
}

\author{
Shaimaa Ghareeb Ahmed Ali \\ Lecturer of Curriculum and TEFL \\ Hurghada Faculty of Education \\ South Valley University
}

\section{1}

\section{Abstract}

\section{Using the Negotiation Strategy for Enhancing EFL Students' Active Listening Skills \\ By Shaimaa Ghareeb Ahmed Ali Ebeed (*)}

The present research aimed at investigating the effectiveness of using the negotiation strategy for enhancing EFL students' active listening skills. The research followed the quasi experimental design of two groups (control and experimental), whereas the researcher designed and used the materials and instruments of the research, which applied on (50) major students of Hurghada Faculty of Education EFL fourth year; that included: a list of the active listening skills, an active listening skills test, a teacher's guide and a student's handbook; which prepared in light of the negotiation strategy. The results of the research showed the statistically significant differences between the mean scores which obtained by the experimental group in the pre/post test of the active listening skills (in favor of the post test). Moreover, there were statistically significant differences between the mean scores of the experimental and the control groups in the post test of the active listening skills (in favor of the experimental group). Therefore, the impact of using the negotiation strategy for enhancing EFL students' active listening skills has been verified.

Keywords: Negotiation strategy, Active listening skills

(*) Lecturer at Curriculum and Instruction Department, Hurghada Faculty of Education, South Valley University 


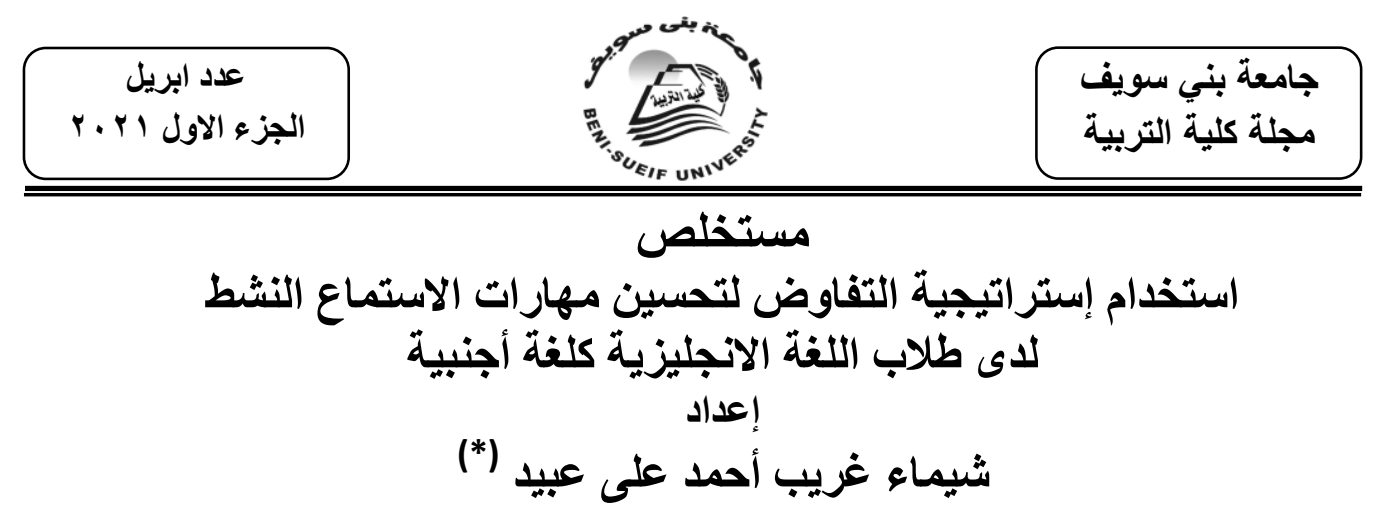

هدف البحث الحالي إلى التحقق من فعالية استخدام إستراتيجية التفاوض لتحسين

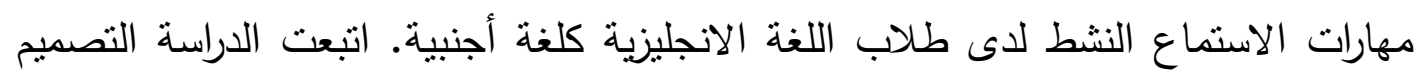

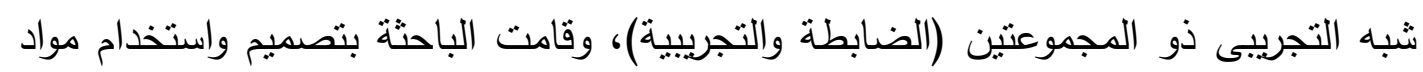

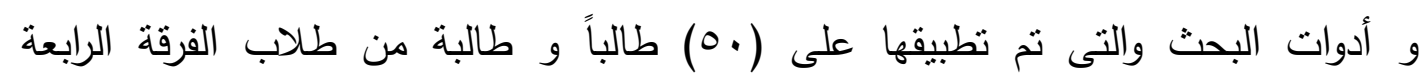

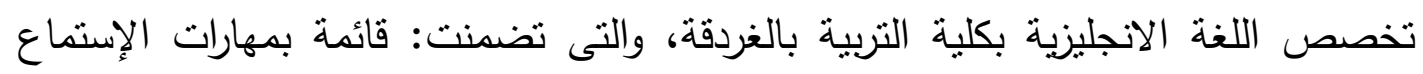

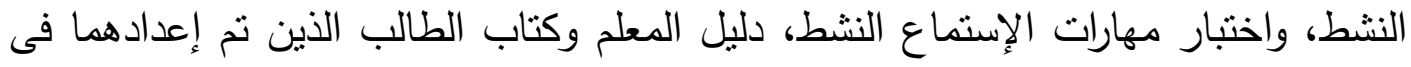

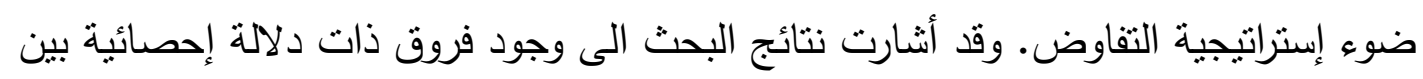
متوسطات الدرجات التى حصلت عليها المجموعة التجريبية فى الإختبار القبلى والبعدى

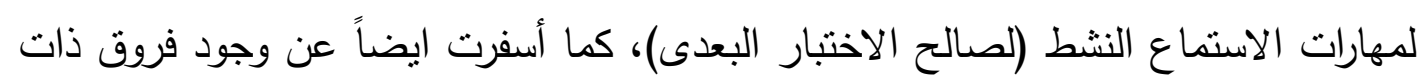

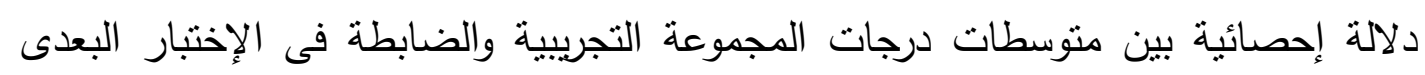

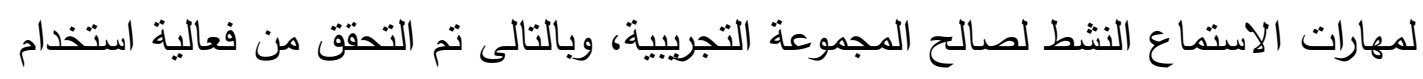

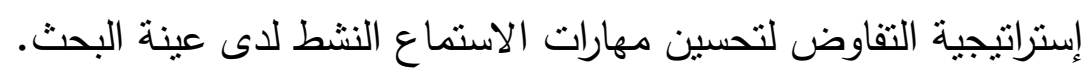
الكلمات المفتاحية: إِتراتيجية التفاوض ، مهارات الاستصاع النثط

(*) مدرس بقسم المناهج وطرق التريس، كلية التربية بالغردقة، جامعة جنوب الوادى 


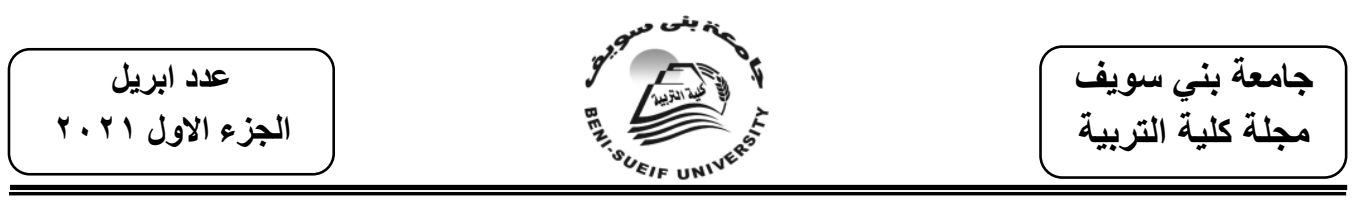

Introduction

Communication is a complex term used differently depending on a situation; it is the act of transmitting and receiving information by using words, sounds, signs or behavior. It is a process through which a certain kind of information is exchanged among individuals. This process is a basic form of social interaction, which is a fundamental characteristic to all human beings.

Listening is one of the most fundamental components of interpersonal communication skills. It is a process by which the listener attempts to gather information from another person to fully understand what is being conveyed (Briggs, 2016). Listening is a very important language skill, not only for communication purposes but also in the process of learning a second language. When people learn a foreign language, listening plays a key role to all effective communication. Without the ability to listen effectively, messages can be inaccurately received and interpreted in the communication process which can lessen their effectiveness and, consequently, lead to misunderstandings. Moreover, in the young learner classroom, listening is pivotal to learning a second language, although, quite often, learners are not taught how to listen properly in a foreign language owing to the fact that in many language classrooms, listening is 'delivered' rather than developed in its own right (Graham, 2011).

There are four levels of listening proficiency; none listening, marginal listening, evaluative listening and active listening; each requiring a particular depth of concentration and sensitivity from the listener. Active Listening (AL) is the highest and most effective level, characterized by willingness and ability to not just simply hear, but also truly understand by listening for the content, intent and feelings of the speaker (Jahromi, 2016). Rogers (1980) theorized that active listeners, '...listen not only with [their] ears, but with [their] eyes, mind, heart and imagination (cited in Robertson, 2005). According to Hennings (1992:3) "To listen is not just to hear; it is the active construction of meaning from all the signals-verbal and nonverbal-a speaker is 
sending". Therefore, teachers ought to make learners aware of the importance of being engaged while actively listening (Linse, 2005) and encourage them to actively develop their own listening skills (Goh \& Taib, 2006).

Active listening is an important communication skill in a variety of disciplines and professions, including the profession of Educational Development. It (also called empathic listening, speaker-listener technique, reflected listening, dialogic listening) is the act of hearing a speaker, avoiding premature judgment, reflecting understanding, clarifying information through restating a paraphrased version of the speaker's message and asking questions, summarizing, and sharing. Active listening involves restating a paraphrased version of the speaker's message, asking questions when appropriate, and maintaining moderate to high nonverbal conversational involvement (Weger, 2014).

Active listening should make people feel better for several reasons. First, the relationship between message evaluations and message outcomes has been established, suggesting that when people evaluate supportive behaviors positively there is a concomitant positive change in affect (High \& Dillard, 2012). Second, active listening is likely to encourage disclosers to express difficult feelings.

Active listening requires the listener to fully concentrate, understand, respond and then remember what is being said. The listener makes a conscious effort to hear and understand the complete message being spoken, rather than just passively hearing the message of the speaker. Various studies stress the importance of listening as a communication skill. The studies on average say that people spend 70$80 \%$ of their waking hours in some form of communication (Barnard, 2017).

In the educational field, Lasky (2000) provided an evidence for the important role of active listening skills in fostering teacher's understanding, and professional development; he suggested that by using active listening skills, education professionals can gain important information with which to work and at the same time communicate to a 


$$
\begin{aligned}
& \text { عدد ابريل }
\end{aligned}
$$

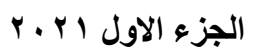

parent a sincere interest in understanding the parent's point of view. Additionally, training teachers in active listening skills help them "to have any ability to help solve problems and satisfy the other person's needs and goals as well as their own. Giving constructive feedback, explored in greater detail depends on a wide range of skills including listening skills and feedback skills" (Hartley \& Bruckman, 2002). Although there is recognition of the need for improved communication between teachers and parents, Lea (2006) confirmed that "at present there are few empirically validated interventions to address the active listening skills of education professionals.

To put it in a nutshell, active listening is a critical communication skill for every human in his personal life. As developing communication skills is one of the main objectives of preparing preservice EFL teachers in Faculties of Education and as effective communication is heavily depending on effective listening, training pre-service teachers on active listening skills is a primary demand for their preparation professionally and academically. Being a teacher requires that he/ she understands their students' points of view, conveys interest and respects for their students.

Rather, active listening is a dynamic process and key in any negotiation (Campolo, 2013); using the negotiation strategy could be an appropriate strategy for EFL listeners to participate actively in interesting dialogues and be encouraged to practice their active listening skills.

Negotiation is a dialogue between two or more people or parties, intended to reach an understanding, resolve point of difference, or gain advantage in outcome of a dialogue, to produce an agreement upon courses of action, to bargain for individual or collective advantage and to craft outcomes to satisfy various interests of two parties involved in negotiation process. Negotiation is a process where each party involved in negotiating tries to gain an advantage for themselves by the end of the process. Therefore, negotiation is intended to aim at compromise. Basically, successful negotiation requires accepting the other person despite differences in values, beliefs, education, ethnicity, or 
perspective. It allows considering an issue from all sides and promoting understanding and interest in the other person without agreeing with his/her point of view (Čulo \& Skendrović, 2012).

Adubato (2012) indicated that great negotiators are great listeners. They don't do a lot of talking and spend much of the time asking smart questions and concentrating on the answers. They also take their time responding to what they've heard as opposed to reacting in an unnecessarily adversarial fashion.

Proficient negotiators actively listen to what their counterparts are saying. They maintain supportive eye contact to encourage counterpart disclosures, and to discern nonverbal signals. Moreover, use smiles and occasional head nods to encourage further responses from counterparts. The proficient negotiators not only hear what is being said, but also recognize what is not being addressed, and they understand that omitted subjects may suggest weaknesses their counterparts do not want to address (Charles, 2016). In addition, negotiators can use active listening skills to help resolve critical incidents involving expressive subjects. Active listening represents a powerful tool to stimulate positive change in others. By using active listening skills, negotiators control the tone of negotiations while they build the empathy necessary to win the subjects' confidence and to resolve tense situations (Gary \& Webster, 1997).

Various studies explore the educational importance and contribution of the negotiation strategy in EFL classroom such as: Gwendolyn (2011), Khorshid (2018), and Kamille (2018). Based on this importance the present research, tried to investigate the effectiveness of using the negotiation strategy for enhancing fourth year English majors students' active listening skills.

\section{Context of the problem}

$>$ As a lecturer in the curriculum and instruction department (TEFL) at Hurghada Faculty of Education, the researcher 


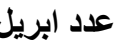

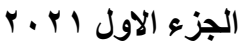

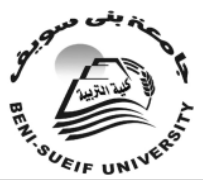

جامعة بني سويف التبة

مجلة كلية التربية

observed the low level of the fourth year English majors' students while practicing the active listening skills. While teaching to those students in EFL course, the following points were observed:

- About eighty percent of the students mentioned that they suffered from insufficient practices of active listening skills.

- About twenty percent of the students stated that they conference their lectures to reach a medium level of the active listening skills.

- Most of the students assured that they lack the ideal method for enhancing their active listening skills.

- About seventy percent of students express their urgent need to enhance their active listening skills as they didn't feel confident about their level.

$>$ Various studies explore the importance of developing active listening skills in various disciplines such as: Briggs (2016), Simonsen \& Klisch (2001), Benoit \& Lee (1988), Sullivan (2011), Weger (2014).

Based on the previous observation and the previous studies, the present research used the negotiation strategy for enhancing EFL students' active listening skills.

\section{Aim of the research}

The present research aimed to:

- Investigate the effectiveness of using the negotiation strategy for enhancing EFL students' active listening skills.

\section{Question of the research}

The present research attempted to answer the following question:

- What is the effectiveness of using the negotiation strategy for enhancing EFL students' active listening skills?

\section{Hypotheses of the research}

The present research tested the following hypotheses: 
عداد ابريل

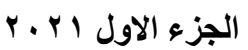

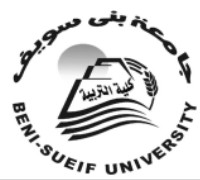

\section{جامعة بني سويف كجان \\ مجلة كلية التربية}

There are statistically significant differences between the mean scores of the experimental group in the pre/post tests of the active listening skills favoring the post test.

$>$ There are statistically significant differences between the mean scores of the experimental group and the control group in the post test of the active listening skills favoring the experimental group.

\section{Significance of the research}

The research was supposed to be significant for the following:

1. Pre/post graduates may benefit from the research in enhancing their active listening skills.

2. Teachers of English may benefit from the research in enhancing their students' active listening skills.

3. Course designers may benefit from the research by using the negotiation strategy to enhance the students' active listening skills.

\section{Delimitations of the research}

The research was delimited to:

1. A sample of fifty fourth year Hurghada Faculty of Education major students because they need to enhance their active listening skills, as this stage precedes more complicated one and need the students to be prepared for the next stage (work). Promoting prospective teachers' active listening skills is a good step in achieving true and good communication with students.

2. Some skills of active listening such as:

- Paraphrasing

- Clarifying

- Asking questions

- Reflecting

- Encouraging 
ع عداد ابريل

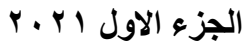

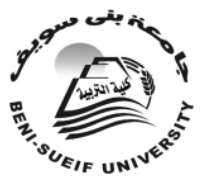

3. The first semester of $20 r \cdot / 2021$.

\section{Materials and instruments of the research}

The researcher designed and used the following:

1. A teacher's guide prepared in light of the negotiation strategy.

2. A student's handbook in light of the negotiation strategy.

3. A list of the active listening skills.

4. An active listening skills test.

\section{Definition of terms}

- Active listening skills

$>$ Briggs (2016) defined "(ALS) are invaluable communication tools, providing an individual with the ability to communicate effectively in settings such as counseling, negotiations, and conflict resolution".

$>$ Mason (2019) defined this term as a technique of understanding the complete message being communicated through words, tones of the voice, and body language".

$>$ are defined procedurally as a combination of abilities that allow the listener to fully concentrate on what the speaker is saying.

- Negotiation

> Čulo \& Skendrović (2012) defined it as a matter of choosing a solution to which no one has an objection.

$>$ is defined procedurally as a conversation between two or more parties, intended to reach an agreement upon an action.

\section{Review of literature}

\subsection{Active listening}

Before shedding light on active listening skill, it is necessary to discuss listening as an active process and its important role in acquiring the other language skills.

- Listening as an interactive skill 
Listening comprehension plays an important role in foreign language teaching. It is more than just hearing; whereas the listener needs to think about the utterances that are being spoken by a speaker. Many linguists and methodologists stress the active nature of listening, Brown (2010), El-Sagheer \& Leviene (2002) and Yang, (2005).

According to Vandergrift (2003: 168),

"It is an active process in which the listener must discriminate between sounds, understand vocabulary and grammatical structures, interpret stress and intonation, construct meaning from the spoken words, and relate what they hear to existing knowledge involves a great deal of mental activity on the part of the listener".

According to the interactive nature of listening, the listener receives the sound waves through the ear and then acts on them, making use of cognitive and affective mechanisms (Brown, 2010: 235). It also requires much effort and practice from the students (El-Sagheer \& Leviene, 2002: 112). Yang (2005:33) added "in order to do well in listening, the listeners must have sufficient knowledge of the language".

Moreover, Steinberg (2007:76) explained that listening is more complex than merely hearing. It is a process that consists of four stages: sensing and attending, understanding and interpreting, remembering, and responding. Further, Caldwell (2008:2) asserted that comprehension is an unobservable process which is extremely complicated and multifaceted in entity. As a result, he defined listening comprehension as "the process of simultaneously extracting and constructing meaning through interaction with oral language". Additionally, Nordquist (2014) stated that listening is an active process of receiving and responding to spoken (and sometimes unspoken) messages.

Listening is assumed to have a more and more important place in foreign language teaching and learning processes. It is considered as one of the most essential skill for both communication and language 


$$
\begin{aligned}
& \text { عدد ابريل }
\end{aligned}
$$

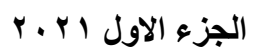

learning. At the same time, it facilities the emergence of the other language skills: speaking, reading and writing. Listening is not only a skill area in language performance, but also a critical means of acquiring a second language. It helps students to acquire good speaking habits as a result of the spoken English they have absorbed, and helps them to improve their pronunciation. Listening texts often provide excellent examples of speaking functions. Additionally, El-Sagheer \& Leviene (2002:4) mentioned that listening to comprehensible input can actually aid language acquisition. As such, listening is considered the channel through which language is naturally acquired.

The highly recognized concept of active listening goes back to the American psychologist "Thomas Gordon". Gordon (2003) mentioned that, "We can never be sure to understand another person completely or in detail. Therefore, it is essential in active listening that the listener frequently and continuously validates the accuracy of understanding in order to keep distortion and misunderstandings at a minimum".

Basically, active listening could be described as a multistep process, including making empathetic comments, asking appropriate questions, paraphrasing and summarizing for enriching communication and completely understanding the speaker's message. Rautalinko \& Lisper (2004) explained the goal in active listening as to develop a clear understanding of the speaker's concern and also to clearly communicate the listener's interest in the speaker's message".

Active listening is a way of listening and responding to another person that improves mutual understanding by involving both verbal and nonverbal communication skills (Kubota, 2004). Additionally, Robertson (2005) mentioned that "while paraphrasing traditionally addresses the level of content, active listening goes further and tries to capture what lies beneath-the feelings that come with what is said".

Furthermore, active listening requires listeners to capture the sender's message from the sender's point of view. The listener has to convey to the sender that he/she understands the message. According to 
ع الاد ابريل

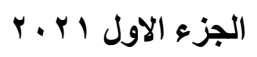

Rautalinko \& Lisper (2004), to listen actively means that" there are several things to do: listening for total meaning, responding to feelings, and paying attention to all cues".

Debasish (2010) suggested that

"Active listening is the most useful and important listening skill. In which the listener is genuinely interested in understanding what the other person is thinking, feeling, wanting. The person is active in checking the understanding before responding. The listener restates or paraphrases the message and reflects it back to the sender for verification. This verification or feedback process is what distinguishes active listening and makes it effective".

\subsubsection{Benefits of active listening}

Barnard (2017) assured that there are many important benefits of active listening, these include:

- Building deep trust: as you cultivate the habit of listening sincerely, you invite people to open up. They can sense that you will not be jumping to conclusions based on superficial details. They also realize that you care enough about them to listen attentively. While building trust takes time, it leads to great benefits such as lifelong friendships and a promise of help in difficult times.

- Broadening your perspective: your own perspective in life is not the complete truth or how everyone else sees it. The way you understand life from your beliefs and thinking is only one way to look at it. Listening to other people's perspectives allows you to look at life from different perspectives, some of which you may not have thought of before.

- Strengthening your patience: the ability to be a good listener takes time and you need to develop it with regular efforts over time. But as you gradually get better and better at listening, an automatic benefit is that you develop patience. Patience to let the other person express his/her feelings and thoughts honestly while you don't judge. 
- Making you approachable: as you present yourself as a patient listener, people feel more naturally inclined to communicate with you. By being there for them, you give them the freedom to express their feelings.

- Increasing competence and knowledge: great listening skills make an employee more competent and capable, regardless of their position. The more an individual can get information out of the meetings, the instructions, and reports provided to him, the more efficient and successful they will be at completing the task. Listening also builds knowledge and helps fulfill work requirements through progressive learning.

- Saving time and money: effective listening not only reduces risks of misunderstanding and mistakes that could be very damaging to the business, it saves time and money by avoiding starting a task or a project over again, just because the directives given were misunderstood. Employees do not waste precious time and a specific budget allocated to a project.

- Helping detect and solving problems: as a leader, they should always be attentive to what employees have to say. In the workplace, they are the first ones to spot flaws and come up with suggestions for improvements. Listening to colleagues will help you understand what needs to be changed and worked on to retain talent and make improvements.

\subsubsection{Techniques of active listening}

Topornycky \& Golparian (2016) and The Writing Centre Learning Guide (2014) identified five key techniques of active listening:

1. Paying attention: by maintaining eye contact with the speaker, putting aside distracting thoughts, avoiding formulating responses while listening, avoiding distractions, and listening to the speaker's body language.

2. Showing that you are listening: by occasionally nodding, smiling, having an open and inviting posture, and encouraging the speaker with small verbal comments such as "yes", "uh huh", etc. 
3. Providing feedback: involves reflection, clarification of the listener's assumptions, and confirmation of the understanding of what was said. This is done through asking clarification questions, paraphrasing, and providing a summary of what was said.

4. Deferring judgment: means allowing the speaker to communicate without interruption, letting them finish each point before asking questions, and refraining from interrupting them with counter arguments.

5. Responding appropriately: means responding openly and honestly, and treating the other persons in a way that the person thinks they would want to be treated.

Valchev (nd) added the following:

- Eye contact: is one basic element of business etiquette and main active listening technique. Eye contact during the conversation shows the speaker that you give him your attention and that you really care about what he says.

- Avoid distractions: the ability to avoid distractions is among the good and active listening skills too. There are so many examples of distractions such as our thoughts, mobile phones, gadgets, music, side activities, other people and more. Learn to avoid these distractions otherwise they can destroy your conversation.

- Body gestures: body gestures and language are a whole science. You need to be very familiar with effective body gestures because they are among the key active listening techniques. Your body gestures tell the speaker whether you listen carefully or not.

\subsubsection{Active listening skills}

Gary \& Webster (1997) discussed the following seven skills of active listening,

\section{$>$ Minimal Encouragements}

During negotiations with a subject, negotiators must demonstrate that they are listening attentively and are focused on the subject's words. Negotiators can convey these qualities either through body 
عداد ابريل

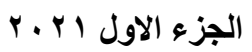

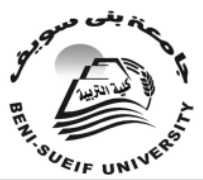

جامعة بني سويفة

language or brief verbal replies that relate interest and concern. The responses need not be lengthy. By giving occasional, brief, and welltimed vocal replies, negotiators demonstrate that they are following what the subject says. Even relatively simple phrases, such as "yes", "O.K.", or "I see", effectively convey that a negotiator is paying attention to the subject. These responses will encourage the subject to continue talking and gradually relinquish more control of the situation to the negotiator.

\section{Paraphrasing}

Paraphrasing consists of negotiators' repeating in their own words the meaning of subjects' messages back to them. This shows that negotiators are not only listening but also understanding what the subject is conveying.

\section{Emotion Labeling}

Emotion labeling allows negotiators to attach a tentative label to the feelings expressed or implied by the subject's words and actions. Such labeling shows that negotiators are paying attention to the emotional aspects of what the subject is conveying. When used effectively, emotion labeling becomes one of the most powerful skills available to negotiators because it helps them identify the issues and feelings that drive the subject's behavior.

\section{Mirroring}

By mirroring, negotiators repeat only the last words or main idea of the subject's message. It serves as both an attending and listening technique, as it indicates both interest and understanding. This skill also frees negotiators from the pressure of constantly directing the conversation. Under stress, negotiators may find they are unsure of how to respond to the subject. Mirroring enables a negotiator to be a full partner in the conversational dance without having to lead. Using this skill also helps negotiators avoid asking questions interrogationstyle, which blocks rapport building. 


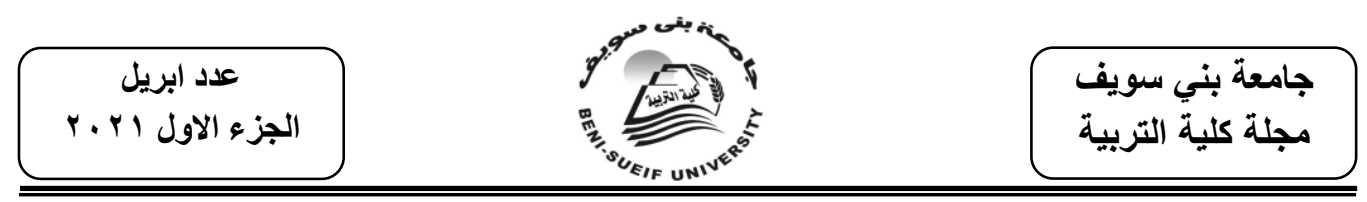

\section{Open-Ended Questions}

By using open-ended questions, negotiators stimulate the subject to talk. Negotiators should avoid asking "why" questions, which could imply interrogation. When the subject speaks, negotiators gain greater insight into the subject's intent. Effective negotiations focus on learning what the subject thinks and feels. If negotiators do most of the talking, they decrease the opportunities to learn about the subject. Additional examples of effective open-ended questions include, "Can you tell me more about that?" "I didn't understand what you just said; could you help me better understand by explaining that further?" and "Could you tell me more about what happened to you today?"

\section{$>$ "I" Messages}

By using "I" messages, a negotiator ostensibly sheds the negotiator role and acts as any other person might in response to the subject's actions. Negotiators express how they feel when the subject does or says certain things. While employing this skill-and all active listening skills-negotiators must avoid being pulled into an argument or trading personal attacks with a subject. An argumentative, sarcastic, or hostile tone could reinforce the subject's already negative view of law enforcement and cause the subject to rationalize increased resistance due to a lack of perceived concern on the part of the police. Use of "I" messages serves to personalize the negotiator. This helps to move the negotiator beyond the role of a police officer trying to manipulate the subject into surrendering.

\section{$>$ Effective Pauses/Silence}

By deliberately using pauses, negotiators can harness the power of silence for effect at appropriate times. People tend to speak to fill spaces in a conversation. Therefore, negotiators should, on occasion, consciously create a space or void that will encourage the subject to 


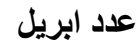

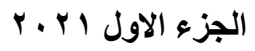

speak and, in the process, provide additional information that may help negotiators resolve the situation.

Silence also is an effective response when subjects engage in highly charged emotional outbursts. When they fail to elicit a verbal response, subjects often calm down to verify that negotiators are still listening. Eventually, even the most emotionally overwrought subjects will find it difficult to sustain a one-sided argument, and they again will return to meaningful dialogue with negotiators. Thus, by remaining silent at the right times, negotiators actually can move the overall negotiation process forward.

Gordon (2000), Briggs (2016), Robertson (2005) and Hoppe (2007: 11-12) suggested a more confined lists of active listening skills which include:

- Restate the information just received with one's own words

○ Reflect the speaker's basic feelings and emotions in words

- Ask questions to get more information

- Restate major ideas expressed including feelings

- Ask questions for vague statements

- Restate wrong interpretations to force further explanation

- Disagree

○ Use varying intonations

$\circ$ Offer ideas and suggestions

Mason (2019) identified ten active listening skills as follows,

- Hearing content: giving feedback, insight, and experiences related to the topic can reinforce that you are hearing what is being said.

- Listening for feelings: helping identify feelings and emotions with words help with understanding. The listener can support the conversation with statements like: "It sounds like you are frustrated" or "I am sensing that you are worried".

- Observing body language: body language can give us cues of others emotions. This may take practice. Things such as: lack of 
عدد ابريل

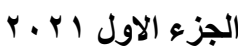

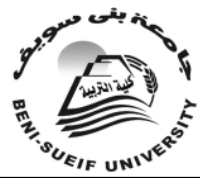

\section{جامعة بني سويف \\ مجلة كلية التربية}

eye contact, moving away, and folding arms are signs of negative emotions, while eye contact, being close, and open arms are signs of neutral and/or positive emotions.

- Neutral technique: listening free of judgment or opinion. Listen to obtain information and gain understanding.

- Paraphrasing: shorting and restating what you heard in the conversation. It shows that what was said was heard.

- Self-Awareness: being aware of your eye contact, body language, tone, and attention is important to active listening. In order to do this you must be paying attention and not thinking about how you are going to respond.

- Reflection: takes the conversation and assesses what feelings are behind the conversation. "It seems like you are afraid of ..." or "Are you feeling afraid because of ....".

- Questioning: asking questions helps to get a deeper understanding of what is being said. "What do you think about....?" or "What would happen if...?"

- Clarifying technique: involves restating what was said as well as asking questions to clarify. "Did I hear you say...?" or "Did you mean.... when you said...?"

- Summarizing: review the facts and check your understanding of the conversation.

\subsubsection{Verbal and non-verbal signs of active listening skills}

Barnard (2017) assured that it's a horrible feeling talking to someone and realizing that they are not really listening. There are some simple steps the listener can take to let the speaker know that you are actively listening, such as asking relevant questions, positive body language, nodding and maintaining eye contact.

\section{$>$ Non-verbal signs of active listening}

People who are listening are likely to display at least some of the following signs. However these signs may not be appropriate in all situations and across all cultures.

- Smile: small smiles can be used to show that the listener is paying attention to what is being said or as a way of agreeing or being happy about the messages being received. Combined with 
ع عداد ابريل

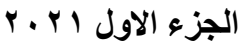

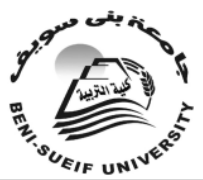

جامعة بني سويف

مجلة كلية التربية

nods of the head, smiles can be powerful in affirming that messages are being listened to and understood.

- Eye contact: it is normal and usually encouraging for the listener to look at the speaker. Eye contact can however be intimidating, especially for more shy speakers gauge how much eye contact is appropriate for any given situation.

- Posture: can tell a lot about the sender and receiver in interpersonal interactions. The attentive listener tends to lean slightly forward or sideways whilst sitting. Other signs of active listening may include a slight slant of the head or resting the head on one hand.

- Distraction: the active listener will not be distracted and therefore will refrain from fidgeting, looking at a clock or watch, doodling, playing with their hair or picking their fingernails.

\section{$>$ Verbal signs of active listening}

- Positive reinforcement: can be a strong signal of attentiveness, however too much use can be annoying for the speaker. Occasional words and phrases, such as: 'very good', 'yes' or 'indeed' will indicate that you are paying attention.

- Remembering: try to remembering a few key points. It can help to reinforce that what is being said has been understood. Remembering details, ideas and concepts from previous conversations proves that attention was kept and is likely to encourage the speaker to continue.

- Questioning: the listeners can demonstrate that they have been paying attention by asking relevant questions and/or making statements that build or help to clarify what the speaker has said. By asking relevant questions the listeners also help to reinforce that they have an interest in what the speaker has been saying.

- Clarification: involves asking questions of the speaker to ensure that the correct message has been received. Clarification usually involves the use of open questions which enables the speaker to expand on certain points as necessary. 


$$
\begin{aligned}
& \text { عدد ابريل }
\end{aligned}
$$

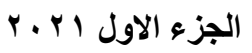

According to the previous views, active listening thus includes three major processes: understanding, paraphrasing and reflecting on the speaker's message. It is listening with a purpose. It is more than just hearing the perceiving sound. Moreover, it involves receiving and interpreting the sounds, creating meaning from the sounds and producing responses explaining the understanding of these sounds. Active listener focuses on the words and the feelings of the speaker for understanding. Active listening happens when the listener hears the various messages being sent, understands their meaning, and then verifies the meaning by offering feedback. Hence, using active listening skills can help to avoid unnecessary conflict. It can also bring clarity and understanding to conversations and interactions with other people.

\section{Negotiation strategy}

Negotiation can occur in a variety of forums, and each forum requires the use of numerous communication tools. The dictionary defines communication as the act of transmitting or conveying information. Negotiation depends on information. Generally, the more information one can get, the better is his/her position to negotiate. To negotiate more effectively, one must relate to the other party with strong communication skills. To be successful in negotiations, it is vital to understand the importance of nonverbal communication which certainly affects the resolution of conflicts and disputes ( $\breve{C u l o} \&$ Skendrović, 2012).

According to Graham (2015), undergraduate students were randomly assigned to disclose a recent upsetting problem to either a trained active listener $(n=41)$ or an untrained listener $(n=130)$. Active listeners were trained to ask open-questions, paraphrase content, reflect feelings, and use assumption checking as well as be nonverbally immediate. Verbal and nonverbal active listening behaviors were rated as signaling more emotional awareness and promoting a greater degree of emotional improvement but did not affect perceptions of relational assurance or problem-solving utility. On average, the set of verbal behaviors were more important in the 


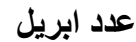

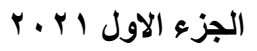

prediction of outcomes compared to the nonverbal behaviors. Results contributed to the larger literature on enacted support, suggested particular roles for active listening techniques within troubles talk.

\subsection{Stages of negotiation}

Shell (2006) distinguished four stages for negotiation process:

1. Preparation. When it comes to preparation, there is basically a need to have a clear idea of how to go about with starting points. One of the keys to effective negotiation is the ability to express own thoughts clearly to the other party.

2. Exchanging information. The information provided to other party must always be well researched and must be communicated effectively. If there are any doubts, they should always be clarified.

3. Bargaining. The bargaining stage could be said to be the most important of the four stages. This is where most of the work is done by both parties. This is where the actual deal will begin to take shape. Bargaining is never easy. Both parties would have to learn to compromise on several aspects to come to a final agreement. This would mean that each party would therefore have to give up something to gain another.

4. Closing and commitment. The final stage would be where the last few adjustments to the deal are made by the parties involved, before closing the deal and placing their trust in each other for each to fulfill their role. The complexity of the negotiating process will vary according to the size and complexity of the proposed deal as well as the attitudes adopted by the parties involved. The actual negotiation process it terms of time and intensity depends on the following factors:

$>$ The goals and interests of the parties,

$>$ The perceived interdependence between the parties,

$>$ The history that exists between the parties,

$>$ The personalities of the people involved, and

$>$ The persuasive ability of each party.

\subsection{Types of negotiation}




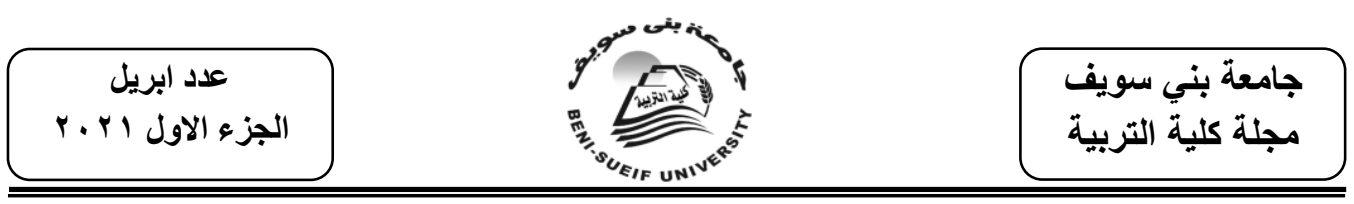

Čulo \& Skendrović (2012) declared that there are two types of negotiation process that differ fundamentally in their approach and in the relative prospects for the stability of the agreement that is reached. The first is called the integrative or win/win approach. In these negotiations the prospects for both sides' gains are encouraging. Both sides attempt to reconcile their positions so that the end result is an agreement under which both will benefit therefore the resultant agreement tends to be stable. Win/win negotiations are characterized by open and empathetic communications and are commonly referred to as partnership agreements. The second is called the distributive or win/lose approach. In these negotiations each of the parties seeks maximum gains and therefore usually seeks to impose maximum losses on the other side. This approach often produces agreements, which are inherently unstable. Capable negotiators understand that the stability of the outcome is important and focus on more than simply maximizing the concessions that can be extracted from the other side.

Zohar (2015) discussed the types and models of negotiation as follow,

(1) One time negotiation: a single, unprecedented occurrence, which offers maximum success in minimum time and yields predictable result in which one or the other party wins and the other loses. There are no expectations for further implications on relations in the future and total attention is focused on successful resolution of the issue at hand.

(2) Continuous negotiations are conducted in the framework of ongoing relationship, such as partners, supplier-client, etc. This type of negotiation is characterized by bearing the influence of experience and the nature of former relationship between the parties. Additionally, it carries each side's expectations for the future, replete with emotional involvement accumulated over the years, which could lead to more conciliatory behavior on the part of both sides.

(3) Direct negotiation whereby continuous personal and direct contact between the involved parties exists. The advantage in this case is also the disadvantage: in other words, the two parties meet with one another directly and see the others' behavior.

(4) Indirect negotiation takes place in the presence of representatives or mediators. The problem here lies in the vested interests of the 


$$
\begin{aligned}
& \text { عدد ابريل }
\end{aligned}
$$

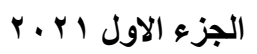

mediators, which might be different from those of the party they are representing. Another problem might be the communication difficulties between the mediators and between parties.

\subsection{Top ten effective negotiation skills}

Kelchner (2019) declared that the ability to negotiate requires a collection of interpersonal and communication skills used together to bring a desired result.

- Problem analysis to identify interests and goals: Effective negotiators must have the skills to analyze a problem to determine the interests of each party in the negotiation. A detailed problem analysis identifies the issue, the interested parties and the outcome goals.

- Preparation before a meeting: Before entering a bargaining meeting, the skilled negotiator prepares for the meeting. Preparation includes determining goals, areas for trade and alternatives to the stated goals. In addition, negotiators study the history of the relationship between the two parties and past negotiations to find areas of agreement and common goals. Past precedents and outcomes can set the tone for current negotiations.

- Active listening skills: Negotiators have the skills to listen actively to the other party during the debate. Active listening involves the ability to read body language as well as verbal communication. It is important to listen to the other party to find areas for compromise during the meeting. Instead of spending the bulk of the time in negotiation expounding the virtues of his viewpoint, the skilled negotiator will spend more time listening to the other party.

- Keep emotions in check: It is vital that a negotiator have the ability to keep his emotions in check during the negotiation. While a negotiation on contentious issues can be frustrating, allowing emotions to take control during the meeting can lead to unfavorable results.

- Clear and effective communication: Negotiators must have the ability to communicate clearly and effectively to the other side during the negotiation. Misunderstandings can occur if the negotiator does not state his case clearly. During a bargaining meeting, an effective negotiator must have the skills to state his desired outcome as well as his reasoning. 
- Collaboration and teamwork: Negotiation is not necessarily a one side against another arrangement. Effective negotiators must have the skills to work together as a team and foster a collaborative atmosphere during negotiations. Those involved in a negotiation on both sides of the issue must work together to reach an agreeable solution.

- Problem solving skills: Individuals with negotiation skills have the ability to seek a variety of solutions to problems. Instead of focusing on his ultimate goal for the negotiation, the individual with skills can focus on solving the problem, which may be a breakdown in communication, to benefit both sides of the issue.

- Decision making ability: Leaders with negotiation skills have the ability to act decisively during a negotiation. It may be necessary during a bargaining arrangement to agree to a compromise quickly to end a stalemate.

- Maintaining good relationships: Effective negotiators have the interpersonal skills to maintain a good working relationship with those involved in the negotiation. Negotiators with patience and the ability to persuade others without using manipulation can maintain a positive atmosphere during a difficult negotiation.

- Ethics and reliability: Ethical standards and reliability in an effective negotiator promote a trusting environment for negotiations. Both sides in a negotiation must trust that the other party will follow through on promises and agreements. The negotiator must have the skills to execute on his/her promises after bargaining ends.

\subsection{Critical components of effective negotiating}

Zohar (2015) discussed four critical components of effective negotiating, which are:

Active listening with four ears, strategic planning, tactical maneuvers, and the use of open-ended questions, which is also utilized in mediation, as a negotiation tactic

\subsubsection{Active Listening with four ears}

A failure to listen effectively can derail every other negotiating skill developed. When listening, a negotiator must wait patiently for insight to emerge and must trust in the outcome of the process. Few individuals are good conversationalists because they think about what 


$$
\begin{aligned}
& \text { عدد ابريل }
\end{aligned}
$$

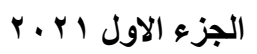

they intend to say, rather than about what the other person is saying. Therefore, the focus of a good conversationalist, as well as a good negotiator, should be not just to hear, but also to listen. Hearing is mostly physical; listening is mostly psychological.

The key to improving listening skills can be accomplished in four steps:

(1) Listen to what is clearly being said.

The first ear involves listening actively (participating, concentrating) to gain insight into the thoughts, needs, and feelings of others. By listening actively and not mentally preparing an immediate reply, one is less likely to convey unintended nonverbal signals. Active listening is a process of thoroughly hearing what the other person has said, and responding with a reflective statement that mirrors what has been heard. Active listening requires expertise in discussing and conferring with, as opposed to bargaining against, in order to hear what the other person is really saying. The negotiator must listen to understand rather than attempt to achieve an agreement or produce some kind of change in the other person.

(2) Listen for what obviously is not being said.

The second ear involves recognizing what speech conceals and what silence reveals. "Listening is the ability to hear what people are saying or not saying as distinguished from the words they enunciate". If one listens between the words, one will be able to discern a message and hear more than just the words. It is important to look not only for the reaction that the other person has to what you have just said, but also for what the other person obviously is not voicing.

The negotiator should use small talk to warm up, should tune into the other person's communicative manner (fast/slow, loud/soft); and should communicate through those senses (seeing, listening, feeling, touching, reasoning) to which the other is more apt to respond. It is unwise to attempt to negotiate with someone who is angry, as that emotion may shape his/her perception of information. Instead, acknowledge feelings of anger first and allow emotional dialogue to precede intellectual discussion so that both parties may listen effectively. Other practical tips for affirming the listening process 


$$
\begin{aligned}
& \text { عدد ابريل }
\end{aligned}
$$

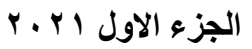

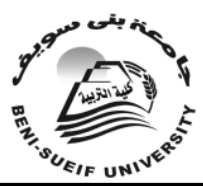

\section{جامعة بني سويف \\ مجلة كلية التربية}

included using your opponent's name as you make eye contact; focusing on issues on which you already agree to build momentum; using the word "yes" for unity, not dichotomy of thought; and speaking only for oneself, thereby acknowledging the other person, his/her authority, and his/her competence.

(3) Listen for what the other person really wants to say, but does not.

The third ear involves listening for the essence of things. A useful reminder is to use the " $\mathrm{e}$ " and "a" and " $\mathrm{r}$ " of "ear": explore what is not clear, acknowledge what is understood, then respond.

(4) Listen to what you are saying to yourself.

The fourth ear involves perhaps the most important part of listening: listening to one's perceptions and the voices from within oneself, the soul's ear. This process often involves subconscious concentration with one's informed intuition acting as a coach. Asking questions results in opening an inner space to receive the reply.

\subsubsection{Plan strategy}

Planning strategy involves focusing on a specific goal as the negotiator uses the power of purpose to prepare, plan, and practice. In preparing, planning, and practicing, a negotiator should use imagination to anticipate and predict what is needed and set justifiable, yet optimistic, aspirations regarding the outcome. Creating the plan prepares the negotiator to expect the unexpected and to look for patterns in the process. While preparing a strategy involves programming one's set of inner signals and prioritizing goals, certain characteristics of effective preparation and practice for negotiation are universal.

\subsubsection{Anticipate tactics}

Just as strategy deals with the overall plan of the negotiation, tactics focus on the details, and implement the strategy. The same ingredients are present: time, power, information, and credibility. Negotiations have a sequence: beginning, during, closing, and after. Different tactics are suitable for these separate stages.

$>$ The beginning is the time to listen and observe, and not the time for debate; a well-worded question is probably the most effective tool at this stage. 


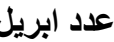

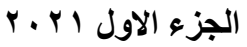

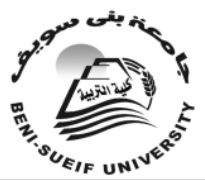

During the negotiation, one moves with more focus. While the beginning phase involves sparring for advantage and the closing is heavily influenced by time pressures, this middle phase is a time primarily for measured movement, exploring interests behind positions, and developing a reasoned approach. Emotions are very effective in negotiating, but keep them under control. Remember also that patience creates a calming, cooperative environment for the resolution of differences and the emergence of successful conclusions. Patience is not a sign of weakness; rather it is leverage that can be used to think critically about the adversary's position and gain insight into the best resolution for both sides.

$>$ Close of the negotiation is the appropriate time to give alternatives, set deadlines for offers to expire, and make the last concession small and conditioned upon agreement. Be conscious of the end of the negotiation approaching because there is less time to correct mistakes.

$>$ After the negotiation process, it is wise to reflect and to plan how to proceed differently next time.

\subsubsection{Open-ended questions}

Encourage the subject to expand on his/her responses in an effort to decrease emotionality and bring the person in crisis to a more rational level. Open-ended questions do not limit the responses to "either-or" or "yes/no answers", but require elaboration and further detail from the subject. Open-ended questions typically start with "What" or "When" or statements such as, "Tell me more about that". "Why" statements are usually avoided, as they tend to be perceived as interrogatory (Gregory, 2005).

Sacristy of studies that investigated the effectiveness of negotiation strategy in EFL classroom, some of them are: Kamille (2018) investigated the negotiations of teachers with students through online resources. Using Goldwich's (2009) framework as guide, the negotiations of the teachers were determined through interviews where five English teachers express how they negotiated and how the use of 


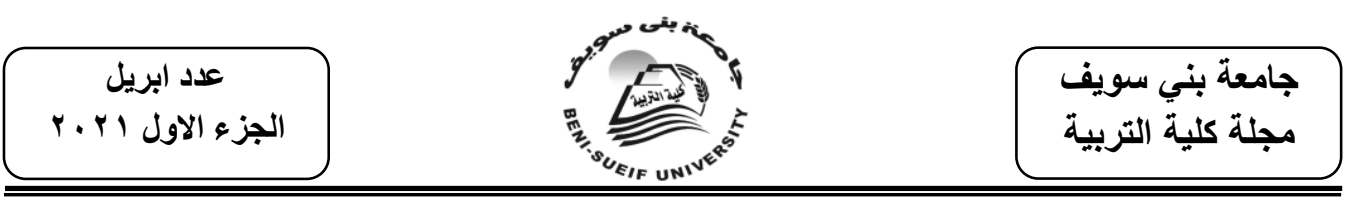

the online resources help in the development of the linguistic competence of students in learning of the English language. The study looked also into the perspectives of the teachers towards the use of technology in their instruction following Davis (1989) Technology Acceptance Model (TAM). After the narratives of the teachers, three themes referring to the negotiation strategies were articulated in this study: snug, simple and, systematic. After evaluating the use of technology in their instruction, the teachers' statements show that the linguistic competence of the students are developed through the constant exposure they have with the activities they conduct online and the tasks they need to accomplish.

Khorshid (2018) investigated the comparison between short and long-term effectiveness of input-providing and outputprompting negotiation strategies on mastering the target structures. To this end, the participants were divided into three groups, namely two experimental groups who had a special kind of treatment, and one control group without any treatment. The participants within the first experimental group received either recasts or confirmation checks as input-providing strategies on errors, whereas the other experimental group participants were exposed to the other types of feedbacks under the category of output prompting strategies and prompts during (10) sessions of teacher-learner interactions with (54) young EFL learners. In addition, the other focus of the study was on the uptake following the above-mentioned strategies. The findings of the present study show that teachers could employ both input- and output-providing strategies judiciously and both seem to be effective.

Gwendolyn (2011) analyzed how international teaching assistants negotiated with their American undergraduate students. Twenty participants engaged in two individual interviews and a videotaped classroom observation where the negotiation strategies were discussed and observed. Findings revealed that although experience improved their negotiation skills, many international teaching assistants struggled with negotiating with students because they did not understand the students' background. Furthermore, cultural norms influenced how 
participants approached the negotiating process. The implications of cultural norms in cross-cultural teacher negotiation are discussed.

\section{Design of the experiment}

The present research used the quasi experimental design of a control and an experimental group of pre/post application of the instruments of the research. The experiment lasted for six weeks, a class period for two days a week. The course selected for this experiment was listening and speaking course presented in the first semester for fourth year graders.

\section{Participants of the research}

Fifty male and female English majoring students were chosen voluntarily from a larger population of Hurghada Faculty of Education, fourth year English majors as the sample of the present research. The experimental group included twenty five male and female students. They were instructed by using the negotiation strategy. The control group included twenty five male and female students. They were instructed by using the traditional method of teaching.

\section{Variables of the research}

\section{$>$ The independent variable is:}

Teaching listening and speaking course using negotiation strategy

\section{$>$ The dependent variable is:}

The active listening skills which include:

1. Asking questions:

- Asking questions to get more information.

- Asking questions for clarification.

2. Paraphrasing:

- Restating the information just said with one's own words.

- Paraphrasing the speaker's main idea.

3. Clarifying

- Clarifying what is said.

- Restating ambiguous or unclear statements.

4. Reflecting: 


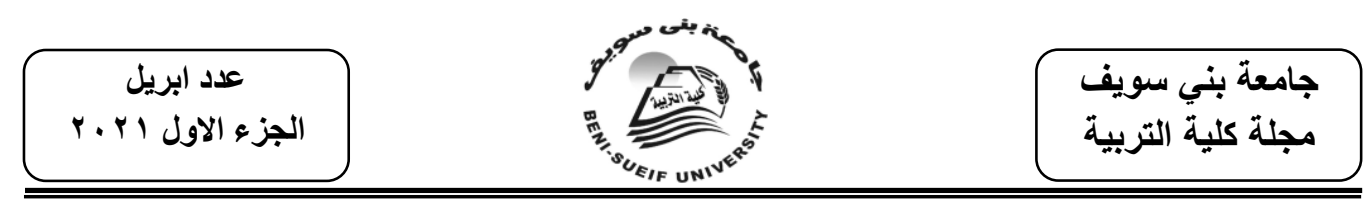

- Identifying the speaker's basic feelings and emotions in words.

- Reflecting the speaker's basic feelings' and emotions in words.

5. Encouraging:

- Using varying voice intonation to convey interest.

- Using follow up expressions to encourage the speaker to keep talking.

\section{Control variables}

To achieve homogeneity between both experimental and control groups of the research, the researcher considered the homogeneity of the participants' age, academic level and English language proficiency.

A) Age: the participants' age level ranged from (20) to (21) years old.

B) Academic level: the participants were all fourth year English majors in Hurghada Faculty of Education.

C) English Language Proficiency: Both groups were subjected to the English Language Proficiency Test for Egypt (EPTE) to achieve their homogeneity with regard to the participants' English language proficiency. The test was developed by the center for developing English Language Teaching (CDELT) (1982), form (A). The test consists of (78) items. It is divided into four parts:

1. Vocabulary: (20) items

2. Grammar: (20) items

3. Listening comprehension: (12) items

4. Reading comprehension: (26) items

The test items are (M.C.Q) items. (1) mark is given for each correct answer. The total score of the test is (78).

Table (1) shows no significant differences between the two groups as the " $T$ " value (1.36) was insignificant at (0.05). 


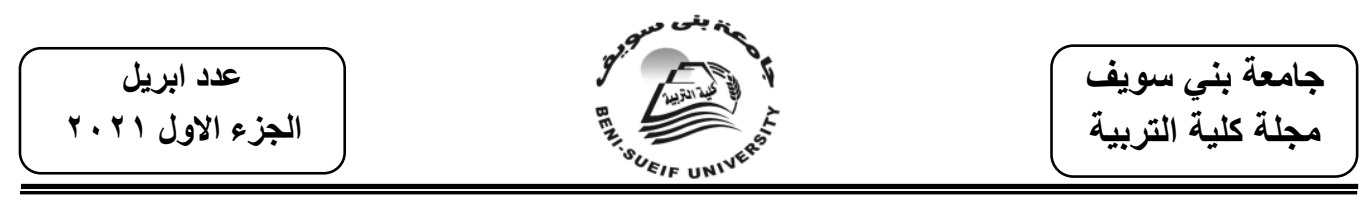

Table (1)

Difference in the Mean of the Control and the Experimental Groups Scores in the Language Proficiency Test

\begin{tabular}{|c|c|c|c|c|c|}
\hline Group & Subjects & Means & SD & DF & "T" Value \\
\hline Control & 25 & 40.97 & 5.94 & \multirow{2}{*}{48} & \multirow{2}{*}{1.36} \\
\hline Experimental & 25 & 38.93 & 5.80 & & \\
\hline
\end{tabular}

Not significant at (0.05) level

\section{Materials and instruments of the research}

\section{A list of the active listening skills}

- Based on the literature review, the researcher prepared a list of the active listening skills and sub skills. The list was submitted to a jury of TEFL specialists, who judged the relevance and suitability of those sub skills to the participants of the research.

- The list was approved by the jury members with few modification in the linguistic stating of the skills and the appropriateness of the skills to the participants of the research.

\section{$>$ Designing the teacher's guide based on the negotiation strategy}

The teacher's guide was designed as a reference for the instructor to describe the procedures, directions, and guidelines for instructing content of the course in light of the negotiation strategy. This teacher's guide aimed to guide the instructors to teach the selected units according to the negotiation strategy.

To design the teacher's guide, the following steps were followed:

1. Reviewing the literature using the negotiation strategy in EFL classrooms.

2. Designing the initial version of it, which should have :

- An introduction including the objectives and how to use it.

- A time schedule for teaching the selected units.

- Suggested teaching procedures for the selected units.

3. Consulting a jury of TEFL experts to judge the suitability of the teacher's guide for teaching the fourth year Faculty of Education English majors, the consistency of it with the procedures of the negotiation strategy, the sufficiency of 


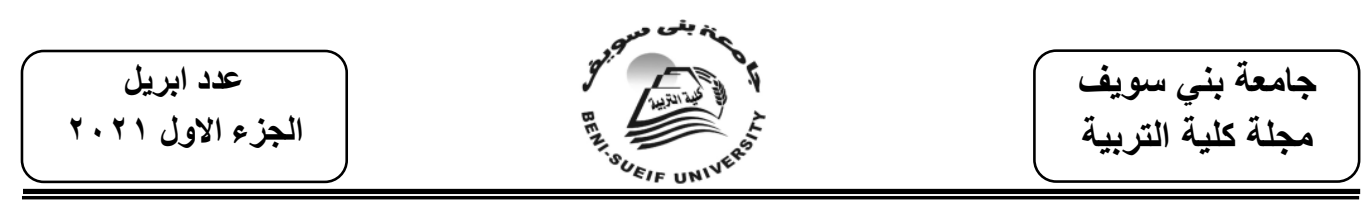

activities and drills, the appropriateness of objectives, teaching aids, and evaluation techniques for students' level.

4. In light of the jury suggestions and recommendations, the following modifications were carried out adding some evaluation items to assess the achievement of all the objectives, modifying some behavioral objectives, and adding more instructions for executing activities.

5. Adapting the teacher's guide and preparing the final version.

\section{Content of the teacher's guide}

The teacher's guide includes two units.

○ Unit one: interesting lives.

○ Unit two: interpersonal relationships.

- Each unit includes five lessons; each lesson was covered in two hours.

- Each unit deals with a general topic related to the students' everyday life.

- Each unit begins with the instructional objectives of the lesson and the teaching procedures which are as follow:

o Preparation. Which include identifying the topic and providing students with structures, forms, examples to help them constructing their opinions and be ready to participate in the negotiation

- Exchanging information. Students are allowed to exchange their opinions, listen to others.

- Bargaining. In which learners learn to compromise on several aspects to come to a final agreement. This would mean that each party would therefore have to give up something to gain another.

○ Closing and commitment. The final stage would be where the last few adjustments to the deal are made by the parties involved, before closing the deal and placing their trust in each other for each to fulfill their role. 
- The topics and texts were selected from the course book presented to the students in first semester of the academic year (2020/2021).

- Most of the activities were practiced in pairs/in groups that encourage students to participate in argumentative dialogues and express their opinions using English language.

- In each lesson, the teaching procedures were prepared according to the negotiation strategy.

- The training techniques were critical reflection, brainstorming, guided discussion, listening actively and drawing dialogues.

- Summative evaluation included a diagnostic test at the end of each unit to determine the extent to which the objectives were achieved and to assess the students' progress in the active listening skills as a result of using the negotiation strategy. The test is oral, in which, every pair of the students was asked to develop a dialogue with each other practicing the required oral tasks.

\section{$>$ Students' handbook}

The students' handbook included instructional objectives, oral activities and quizzes, handouts, evaluation unit and in class activities and quizzes. It also includes scripts of the audio texts.

\section{The active listening skills test}

\section{$\checkmark$ Aim of the test}

The test was used:

1. Pre: to establish the equivalence of the experimental and control groups.

2. Post: to investigate the effectiveness of using the negotiation strategy for enhancing fourth year English majors' performance in the selected active listening skills.

\section{$\checkmark$ Construction of the test}

Before constructing the test, a table of specifications was developed to specify the content and the number of items included to guarantee that the intended learning outcomes were measured, and assure that the number and type of items were suitable for assessing all the desired objectives. The test was in the oral form and consisted of reciprocal 
exchanges where both the examiner and the students had to adjust messages and take each other's' contributions into account. Questions in each task were presented according to the degree of their difficulty, so that, they ranged from easy to difficult. It consisted of two sections:

- The first section included various scenarios followed by a number of open-ended questions. Students listened actively to the examiner while narrating each scenario and practicing the tasks that followed.

- The second section included a reading text followed by a conversation to discuss points mentioned in this text. The students read the text and listen to the conversation then answer the questions that follow.

The students were not allowed to repeat again or record again when they made errors. The examiner adopted different techniques to extract answers, especially from timid and shy students (calming down, speaking friendly, using probing questions and yes/no questions).

The examiner should avoid:

- Correcting the students' errors,

- Interrupting the student unless necessary,

- Giving a specific feedback,

- Giving more explanation about the given questions.

\section{$\checkmark$ Scoring the test}

The total test score was (30) marks, (3) scores were given for each productive oral question; based on the following criteria:

- Clarity

- Correctness

- Fluency

\section{$\checkmark$ Instructions of the test}

The instructions of the test were presented in English. They were brief, simple to understand and free from any possible ambiguities. They contain information about the aim of the test, time allowed to complete it and how to show the answers. 


\section{Piloting the test}

It was conducted prior to the real administration of the test. Thirty students were chosen from fourth year English majors to participate in this application. Those students were excluded from participating in the real experiment. The piloting aimed to:

1. Ensure the clarity of instructions,

2. Measure the suitability of the linguistic level to the participants, and

3. Determine the validity, reliability and duration of the test.

In light of the pilot study, it was found that period of (30) minutes would provide enough time to perform the active listening test. In addition, the results of the pilot study of the test confirmed the clarity and the suitability of the test items to the students in terms of content and assessment task type.

\section{$\checkmark$ Content Validity of the test}

The test was submitted to the jury members to report its validity according to the following criteria:

- The linguistic stating of the items.

- Whether the items measure how far objectives have been achieved.

- Suitability of the reading and audio passages for the subjects.

- Its applicability and fitness.

There was a consensus that the test was comprehensive and covered the course content, the aim and the intended learning outcomes.

\section{$\checkmark$ The reliability of the test}

It was determined by using Cronbach Alpha formula. The reliability coefficient of the test $(0.775)$ and it was found to be significant at (0.01) level which is acceptable by Allam (2000).

\section{Procedures of the experiment}

To execute the experiment, the following procedures were done:

\section{Pre testing}


The pre test was handled in the faculty lab, which lasts for four days, four hours a day. Results of the pre testing ensure that there are no statistically significant differences between the mean scores of the experimental group and the control group in the pre test of the active listening skills.

\section{Table (2)}

Differences in the mean scores of both groups in the active listening skills pre-test

\begin{tabular}{|c|c|c|c|c|c|c|c|}
\hline $\begin{array}{c}\text { Administrat } \\
\text { ion }\end{array}$ & Groups & $\mathbf{N}$ & Means & $\begin{array}{c}\text { Standard } \\
\text { Deviation }\end{array}$ & $\begin{array}{c}\text { Degree of } \\
\text { Freedom }\end{array}$ & $\begin{array}{c}\text { "T" } \\
\text { Value }\end{array}$ & Significance \\
\hline \multirow{2}{*}{ Pre testing } & Control & 25 & 8.2800 & 2.13151 & & & \\
\cline { 2 - 7 } & Experimental & 25 & 8.4000 & 1.87083 & 48 & .212 & NS \\
\hline
\end{tabular}

\section{$>$ Teaching}

The researcher taught to the experimental group using the negotiation strategy. Every participant of the experimental group received a written copy of the student handbook which includes the activities and tasks they had to practice.

\section{Post testing}

After teaching the content, the post active listening skills test was readministered to the participants in order to measure the effectiveness of using the negotiation strategy on their language skills and to compare the performance of both groups.

4.

\section{Results and findings}

The quasi experimental design of the research depended on comparing students' scores in the test before and after teaching instructing with the negotiation strategy, and comparing the students' scores of both the control and the experimental groups in the active listening skills test. The researcher analyzed the quantitative data using "T" test formula. 


\section{Hypothesis (One)}

There are statistically significant differences between the mean scores of the experimental group in the pre/post tests of the active listening skills favoring the post test.

\section{Table (3)}

Analysis of scores of the experimental group in the pre/post testing of the active listening skills

\begin{tabular}{|c|c|c|c|c|c|c|}
\hline Administration & $\mathbf{N}$ & Means & DF & SD & $\begin{array}{c}\text { "T" } \\
\text { Value }\end{array}$ & Significance \\
\hline Pre & \multirow[b]{2}{*}{25} & 8.4000 & \multirow[b]{2}{*}{24} & 1.87083 & \multirow[b]{2}{*}{21.118} & \multirow[b]{2}{*}{0.01} \\
\hline Post & & 24.9600 & & 3.44577 & & \\
\hline
\end{tabular}

Table (3) showed that the mean scores gained by the students of the experimental group are higher in the post testing of active listening skills than those obtained in the pre testing. "T" value is (21.118) which is significant at $(0.01)$ level. These high gains of the students in the post testing of active listening skills could be due to teaching using the negotiation strategy. The results of this hypothesis revealed that the instruction by using the negotiation strategy was effective in enhancing the active listening skills of the experimental group according to Blake's modified gain ratio (1.32).

\section{Hypothesis (Two)}

There are statistically significant differences between the mean scores of the experimental group and the control group in the post test of the active listening skills favoring the experimental group.

\section{Table (4)}

Differences in the mean scores of both groups in the active listening skills post test

\begin{tabular}{|c|c|c|c|c|c|c|c|}
\hline $\begin{array}{c}\text { Administr } \\
\text { ation }\end{array}$ & Groups & $\mathbf{N}$ & Means & $\begin{array}{c}\text { Standard } \\
\text { Deviation }\end{array}$ & $\begin{array}{c}\text { Degree of } \\
\text { Freedom }\end{array}$ & $\begin{array}{c}\text { "T" } \\
\text { Value }\end{array}$ & $\begin{array}{c}\text { Signific } \\
\text { ance }\end{array}$ \\
\hline \multirow{2}{*}{ Pre testing } & Control & 25 & 15.2800 & 3.03480 & & & \\
\cline { 2 - 8 } & Experimental & 25 & 24.9600 & 3.44577 & 48 & 10.541 & 0.01 \\
\hline
\end{tabular}


Table (4) showed that there were statistically significant differences between the mean scores of the control and experimental groups at (0.01) in the active listening skills test in favor of the experimental group. This result indicated that instructing the students by using the negotiation strategy had a positive and a higher effect in enhancing the active listening skills than what the traditional method had according to Etta Square formula (0.950) which indicated a high size of effectiveness.

\section{Discussion}

The present research investigated the effectiveness of using the negotiation strategy for enhancing fourth year English majors' active listening skills. The results obtained from the post test indicated that the participants of the experimental group achieved significant enhancing in the active listening skills after being instructed through the negotiation strategy. That could be due to many reasons. One of these reasons was that the negotiation strategy was based on the constructivism theory which emphasizes the students' participation and involvement in the process of learning, and promotes students' ability to think, decide and express.

The activities and tasks contributed in enhancing the participants' target active listening skills. The students involved in various activities in each lesson such as reflecting, asking questions, taking notes, analyzing and role playing. Furthermore, the participants were asked to work in pairs and in groups to achieve the stated objectives of each lesson. Moreover, continuous evaluation techniques were given at the end of the lesson which contributed to the enhancement of the students' performance. After each oral task either in pairs or in groups, the participants were given an immediate feedback explaining the errors involved and correction.

The participants' responses in the pre test showed that they were at a low level of active listening skills. Most of their responses were of nonverbal, they hardly produce a word or two to respond actively to the 


$$
\begin{aligned}
& \text { عدد ابريل }
\end{aligned}
$$

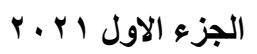

oral questions. Most of the participants had difficulty in how to reflect on the speaker's feelings, as they hardly could restate the speaker's message, and they couldn't show any response reflecting on his/her feelings. Some of the participants had difficulty in encouraging speakers to keep talking or paraphrasing the speaker's words in a fluent way. Related to the reflecting and paraphrasing skills, some students were hesitant while answering questions and lacked of comprehension.

After being instructed through the negotiation strategy, the participants' active listening skills enhanced highly. These results may be due to several reasons: the students were exposed to enough experience of active listening skills, and therefore, enough training for the students could be a reason for their ability to perform better. This research provided evidence that focused training in the use of active listening skills can produce an observable enhancement in these skills.

To conclude, instruction by using the negotiation strategy promoted fourth year English majors' active listening skills. The results of the present research added to the results of Gwendolyn's study (2011) which revealed that using the negotiation strategy had a positive effect on teaching English and developing students' performance. The study of Ammer (2017) revealed the contribution of the negotiation strategy in improving speaking skills and reducing test anxiety. It also was in consistence with the studies of Khorshid (2018); Kamille (2018) which revealed that negotiation instruction have a positive effect on learner's achievement, learning and success.

\section{Recommendations of the research}

In light of the previous findings, the researcher recommends the following:

- More training should be done for promoting active listening skills of prospective teachers.

- Active listening skills could be developed in accordance with speaking skills. 
- Using the negotiation strategy promotes EFL students' abilities to ask questions, reflecting on what they have listened to.

\section{Suggestions for Further researches}

- Using the negotiation strategy to develop fourth year English majors' speaking skills.

- Using the negotiation strategy to develop fourth year English majors' communication skills.

- Using the negotiation strategy to develop fourth year English majors' critical thinking skills. 


$$
\begin{aligned}
& \text { عداد ابريل }
\end{aligned}
$$

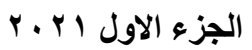
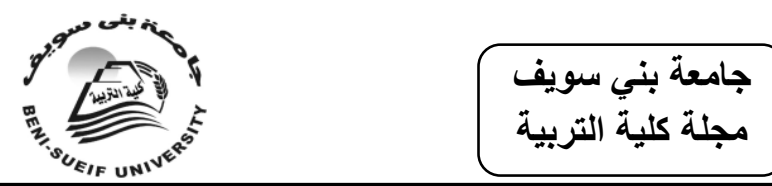

\section{References}

Adubato, S. (2012). Negotiation and Communication: Perfect Together. The Star Ledger, New Jersey online newspaper.

Ammer, M. (2017). The Effect of Meaning Negotiation Strategy Instruction on the Speaking Proficiency and Anxiety Reduction of Egyptian First Year Secondary School. Faculty of Education Journal, Tanta University, 67(3), 32-57.

Barnard, D. (2017). Active Listening Skills, Examples and Exercises. Available at https://virtualspeech.com/blog/active-listening-skills-examples-andexercises

Benoit, S., \& Lee, L. (1988). Listening: It can be taught!. Journal of Education for Business, 229-232.

Briggs, K. (2016). Active Listening Skills. Pivotal Points, Petaluma, California 94953, available at

https://www.bcbsnd.com/content/dam/bcbsnd/documents/general/AL S\%20Handout.pdf

Brown, H. (2010). Teaching by principles: An interactive approach to language Pedagogy. (4th ed.). New York: Longman, Inc.

Caldwell, S. (2008). Comprehension Assessment: A Classroom Guide. Guilford Press

Campolo, J. (2013). Negotiation and Active Listening Skills: Talk Less and Listen More. Available at https://cmmllp.com/negotiation-active-listeningskills-talk-less-listen/

Charles, B. (2016). Classic Negotiation Techniques, 52, IDAHO L. REV. 425-462.

Čulo, K. \& Skendrović, V. (2012). Communication in the Process of Negotiation. Faculty of Civil Engineering, Josip Juraj Strossmayer University, Professional Paper, Informatol. 45, 4, 323-327.

Davies, G., \& Hewer, S. (2012). Introduction To New Technologies and How They Can Contribute To Language Learning and Teaching. Module. In Davies G. (ed.), Information and Communications Technology for Language Teachers (ICT4LT) Slough, Thames Valley University [Online]. Available at: http://www.ict4lt.org/en/en_mod1-1.htm

Debashish, S. (2010). Business Communication. PHI Learning PVT. Ltd.

El-Sagheer, A. \& Leviene, L. (2002). Teaching Listening. In Z. El-Naggar et al. (eds). Spotlight on primary English education_resources (SPEER). Washington: Academy for Educational Development.

Gary, W. \& Webster, M. (1997). Crisis Intervention: Using Active Listening Skills in Negotiations. Available at http://www.wshna.com/yahoo_site_admin/assets/ docs/Active_Listening_Skills_Webster_Noesner_.307125550.pdf 


$$
\begin{aligned}
& \text { عدد ابريل }
\end{aligned}
$$

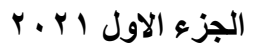

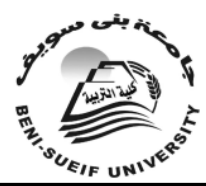

\section{جامعة بني سويف مجلة كلية التربية}

Goh, C., \& Taib, Y. (2006). Metacognitive Instruction in Listening For Young Learners. ELT Journal, 60(3), 222-232.

Goldwich, D. (2010). Win-Win Negotiations: Developing the Mindset, Skills and Behaviors of Win-Win Negotiators. Singapore, Marshall Cavendish Business.

Gordon, T. (2000). The Origins of the Gordon Model. Retrieved (28 February, 2016) from http://www.gordontraining.com/thomas-gordon/originsof-the-gordon-model/,

Gordon, T. (2003). Teacher effectiveness training. New York: Three Rivers Press.

Graham, D., Andrea, J., Cannava, K., \& Susanne, M. (2015). The Role of "Active Listening" in Informal Helping Conversations: Impact on Perceptions of Listener Helpfulness, Sensitivity, and Supportiveness and Discloser Emotional Improvement. Western Journal of Communication, 79(2), 151-173, DOI: 10.1080/10570314.2014.943429

Graham, S., Santos, D., \& Vanderplank, R. (2011). Exploring The Relationship Between Listening Development and Strategy Use. Language Teaching Research, 15(4), 435-456.

Gregory, M., Vincent, B., \& Stephen, J. (2005). Crisis (Hostage) Negotiation: Current Strategies And Issues In High-Risk Conflict Resolution. Aggression and Violent Behavior, 10, 533-551.

Gwendolyn, M. (2011). Examining Classroom Negotiation Strategies of International Teaching Assistants. International Journal for the Scholarship of Teaching and Learning, 5(1), Article 21, 1- 16

Hartley, P. \& Bruckmann, C. (2002). Business Communication, London, Worldcat.

Hennings, D. (1992). Beyond The Read Aloud: Learning To Read Through Listening To And Reflecting On Literature. Bloomington, IN: Phi Delta.

High, A., \& Dillard, J. (2012). A Review and Meta-Analysis of Person-Centered Messages and Social Support Outcomes. Communication Studies, 63, 99-118, doi: $10.7080=10510974.2011 .598208$

Hoppe, M. (2007). Lending An Ear: Why Leaders Must Learn To Listen Actively. Leadership in Action, 27(4), 11-14.

Jahromi, V., Tabatabaee, S., Abdar, Z., \& Rajabi, M. (2016). Active Listening: The Key Of Successful Communication In Hospitals. Electron Physician, 8(3), 2123-2128. doi: http://dx.doi.org/10.19082/2123. Retrieved fromhttps://www.ncbi.nlm.nih.gov/pmc/ articles/PMC4844478/ pdf/epj-08-2123.pdf

Kamille, C., \& Camilla J. (2018). Communication Negotiation Strategies of Senior High School English Teachers with Students Using Online Resources. Journal on English Language Teaching, 8(4), 1-15. 


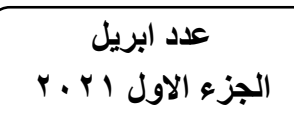
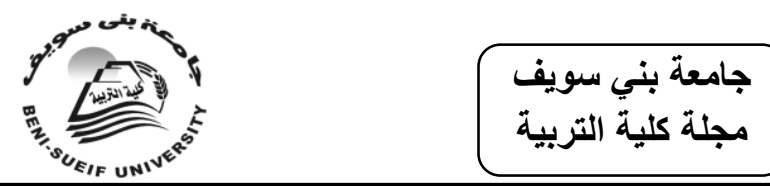

Kelchner, L. (2019). Top Ten Effective Negotiation Skills. Available at https://smallbusiness.chron.com/top-ten-effective-negotiation-skills$\underline{31534 . h t m l}$

Khorshid, M., Parviz, A., \& Gholami, J. (2018). Input Providing vs. OutputPrompting Negotiation Strategies in Learning Grammar among Young EFL Learners. International Journal of Instruction, 11(2), 497-512

Kubota, S., Mishima, N., \& Nagata, S. (2004). A Study of the Effects of Active Listening on Listening Attitudes of Middle Managers, Journal of Occupational Health, 46, 60-67.

Lasky, S. (2000). The Cultural and Emotional Politics of Teacher-Parent Interactions. Teaching and Teacher Education, 16, 843-860.

Lea, D. (2006). 'You Don't Know Me Like That': Patterns of Disconnect Between Adolescent Mothers of Children With Disabilities and Their Early Interventionists. Journal of Early Intervention, 28, 264-282.

Linse, C. (2005). Practical English Language Teaching: Young Learners. New York:

McGraw-Hill ESL/ELT.

Mason, L. (2019). Teaching Active Listening to Your Child. Available at https://www.signingtime.com/parenting-articles/teaching-activelistening-to-your-child/

Nordquist, R. (2014). Listing (Composition). (Online), retrieved from (http://grammar.about.com/od/il/g/Listing.htm), retrieved July 4th, 2020.

Rautalinko, E. \& Lisper, H. (2004). Effects of Training Reflective Listening In a Corporate Setting. Journal of Business and Psychology, 18(3): 281299.

Robertson, K. (2005). Active Listening: More than Just Paying Attention. University of Melbourne, Australian Family Physician, 34(12), 10531055. Retrieved from https://www.racgporgau.ezproxy.uws.edu.au/afpbackissues/2005/200 512/200512robinson.pdf

Shell, R. (2006). Bargaining for Advantage: Negotiation Strategies for Reasonable People“. Penguin Book.

Simonsen, A., \& Klisch, K. (2001). Managing Conflict with "Class". Parks \& Recreation, 36(12), 76-79.

Steinberg, S. (2007). An Introduction to Communication Studies. Juta and Company Ltd, Cape Town, South Africa.

Sullivan, A. (2011). The Importance of Effective Listening Skills: Implications for the Workplace and Dealing with Difficult People. University of Southern Maine. 
عاد ابريل

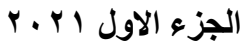

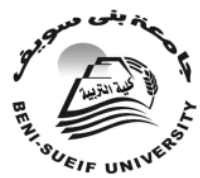

\section{جامعة بني سويف مجلة كلية التربية}

Topornycky, J. \& Golparian, Sh. (2016). Balancing Openness and Interpretation in Active Listening. University of British Columbia, CELT (Collected Essays on Learning and Teaching), IX, 175-184.

Valchev, M. (nd). Active Listening Skills \& Techniques: The Ultimate List. Copyright by Business Skills \& Software, Available at https://www.businessphrases.net/active-listening-skills/

Vandergrift, L. (2003). Facilitating Second Language Listening Comprehension: Acquiring Successful Strategies. ELT J, 53(3): 168-176.

Weger, H., Castle, G., Minei, E. \& Robinson, M. (2014). The Relative Effectiveness of Active Listening In Initial Interactions. International Journal of Listening, 28, 13-31. http://dx.doi.org/10.10 80/10904018.2013.813234 VIEW ITEM

Writing Centre Learning Guide. (2014). Active Listening. The University of Adelaide, Seek Light, 1-4.

Yang, Z. (2005). Listening Outside the Classroom. US-China Foreign Language, 3(9), 33-35.

Zohar, I. (2015). "The Art of Negotiation" Leadership Skills Required For Negotiation in Time of Crisis. International conference "Education, Reflection, Development", 3-4 July, Cluj-Napoca, Romania, Procedia - Social and Behavioral Sciences, 209, 540-548.

علام، صـلاح الدين محمود. ( . . . ب). القياس و التقويم التربوى و النفسى، أساسياته وتطبيقاته وتوجهاته

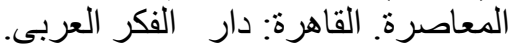

